\title{
QUALITY CONTROL ON DAIRY FARMS WITH EMPHASIS ON PUBLIC HEALTH, FOOD SAFETY, ANIMAL HEALTH AND WELFARE
}

\author{
J. P. T. M. Noordhuizen, J. H. M. Metz
}

\section{Introduction}

The quality of food of bovine origin has become an increasing issue for consumers over the last decade, not in the least given the recent accidents in the dairy sector like bovine spongiform encephalopathy (BSE), verotoxigenic E. coli (VTEC), chronic wasting in cattle, recall of penicillin-containing consumption milk. At the same time outbreaks of various diseases in Europe like food and mouth disease have induced concern of the general public about the way that food animals are being kept.

Today, consumers have quite an impact on animal production in Europe especially regarding the husbandry system, animal health care and animal transportation. The European Commission has prioritized consumer protection in its policy, installed the precautionary principle, and recently created the European Food Safety Authority, EFSA. A recent directive (97-12) and regulation (1782002) point to the need to monitor farms for food safety, public health, animal health and welfare. Liability, quality control and demonstration of status and activities become paramount.

In that respect "quality" can no longer be associated with the product alone but should be extended to the production process itself. Animal health, animal welfare, food safety and public health have become primary issues in policy, in retailer strategy, in consumer concern and ultimately among the producers themselves. Several food production sectors have already implemented integrated quality assurance programmes throughout the whole chain, including the farms. Examples are the cattle quality management programmes in Australia (Ryan, 1997) and Scandinavia (Knuds on, 1997).

Rad je priopćen na "54 ${ }^{\text {th }}$ Annual Meeting of the EAAP", Roma 2003.

J. P. T. M. Noordhuizen, Dept. of Farm Animal Health, Faculty of Veterinary Medicine, University of Utrecht, PO Box 80151, 3508 TD Utrecht, The Netherlands; J. H. M. Metz, Dept. of Agro-technology \& Food sciences, Farm technology Group, Wageningen University, PO Box 43, 6700 AA Wageningen, The Netherlands. 
For the dairy sector as a whole the question is, how such quality assurance should be designed and in which way the forenamed issues can be addressed on farms, preferably in an integrated manner. These topics are addressed in this paper and some examples from the field are given.

\section{Quality and quality concepts}

\section{Quality}

The term "quality" refers to the expectations clients have regarding a certain service or product. Implicitly it refers to both the technical features of the product, the production process from which the product originates and the perception that the client has about both. The general public nowadays has little knowledge about agro-production. Its perception is largely determined by the calamities that occur and that attract the media. It appears not to be easy to change this perception by extension and explaining the production methods. At the same time the dairy industry is highly susceptible for incidents affecting the public image of their products. It means that all efforts have to be directed toward the quality features of the product and the production process that have direct association with the consumer concern. As stated above, this refers first of all to food safety, public health, animal health and animal welfare, and next, to the more classic, technological quality measures like milk cell counts, bacteria counts, antibiotic residues, and freeze point decrease.

Actually all these measures and features should be brought under a quality control programme. The question then rises what kind of programme would be best choice and how should it be executed.

\section{Quality control concepts}

There are different concepts for quality control: good manufacturing practice, GMP; international standardization office, ISO; systems, hazard analysis critical control points, HACCP; total quality management, TQM (Evans \& Lindsay, 1996). The most relevant characteristics of three of these when applied at dairy farm level have been scrutinized by Noordhuizen \& Welpelo (1996) and results are given in Table 1.

GMP refers to rather an attitude or mentality oriented approach than a true quality assurance programme. 
Table 1. - THE MOST RELEVANT CHARACTERISTICS OF THREE DIFFERENT QUALITY CONTROL CONCEPTS FOR APPLICATION AT DAIRY FARM LEVEL (Noordhuizen \& Welpelo, 1996)

\begin{tabular}{lccc}
\hline Characteristic & GMP code & HACCP concept & ISO system \\
\hline Approach & Top-down & Bottom-up & Top-down \\
Orientation & Process & Process (+ product) & System \\
Farm-specific & No & Yes & No \\
Simplicity level & Moderate & Yes & No \\
Self-management level & Moderate & High & Low \\
Corrective measures & No & Yes & Yes \\
Labour demand & Low & Moderate & High \\
Expected costs input & Low & Low & High \\
Easy to link to operational management & Moderate & High & Low \\
Documentation need & Low & Moderate & High \\
Easy to link to food chain quality assurance & No & Yes & Yes \\
Health demonstrable & No & Yes, specific & Yes, general \\
Fit for certification & No & Yes & Yes \\
\hline
\end{tabular}

The HACCP concept is the best choice if a quality control programme should be designed for dairy farms. Particularly because it is highly farm-specific, easy to link up with operational management, relatively low in cost, both product and process oriented, and not requiring much labour. ISO is very laborious and costly as well as far too non-specific to make it truly workable for a dairy farmer. In any case, a sound quality attitude of farmers and others involved is needed before one should even think about introducing HACCP or ISO.

The HACCP concept deals with hazard and risk identification, process decomposition, designation of critical control points, the set-up of an on-farm monitoring programme, the documentation and the verification of the programme. Risk identification and risk management play a pivotal role in the concept. The concept of TQM according to Evans \& Lindsay (1996) can be considered as a merger of GMP and HACCP concepts. Hence, literature sometimes mixes up the concepts of HACCP and TQM.

Before we address the application of the HACCP concept at the dairy farm, we will first consider the hazards and risks associated with public health, food safety, animal health and animal welfare.

Hazards and risks

Animal health and public health

Health disorders can be infectious or non-infectious in nature. Next to monocausal disorders on a dairy farm like food and mouth disease, these 
disorders usually have a multicausal background. This means that different conditions or factors at the level of the animals (age, parity, lactation stage, breed, immune status), as well as at the level of farming areas (housing, nutrition, climate, management) all together contribute to the occurrence of such disorders. Based on the fact that these conditions may differ widely between dairy farms, the prevalence of disorders will equally differ substantially between farms. The conditions are risk factors; they can be tabulated in a qualitative manner as can be found in most textbooks for diseases, but can also be quantified epidemiologically in terms of odds ratios or relative risks (Thrusfield, 1997; Noordhuizen et al., 2001; Schouten et al., 2001). Examples are given in Table 2 for the bovine claw disorder "Mortellaro disease" (Frankena et al. in Noordhuizen et al., 2001).

Table 2. - SOME SIGNIFICANT ODDS RATIOS (OR) FOR MORTELLARO DISEASE IN CATTLE

\begin{tabular}{lcc}
\hline Parity & 1 & 1.3 \\
& 2 & 1.1 \\
Breed & 3 & 1.0 (ref.) \\
& $>50 \% \mathrm{HF}$ & 1.2 \\
& $>50 \% \mathrm{FH}$ & 1.02 \\
& $>50 \% \mathrm{MRU}$ & 0.1 \\
Lactation slage Dry & $\mathrm{HF}{ }^{*} \mathrm{FH}$ & 1.0 (ref.) \\
& & 0.3 \\
& Pre-top & 0.8 \\
Access to pasture Limited & Top (50-70) & 1.7 \\
Walking distance $>$ 200 $\mathrm{m}$ & Past-top & 1.0 (ref.) \\
& & 1.5 \\
Walking path & Free & 1.0 (ref.) \\
& & 5.4 \\
& $<200 \mathrm{~m}$ & 1.0 (ref.) \\
& Metalled & 2.6 \\
\end{tabular}

Frankena et al. in: Noordhuizen et al., 2001.

$\mathrm{OR}=1$ means no association (reference value); OR $>1$ means risk increase; $\mathrm{OR}<1$ means risk decrease.

The items in Table 2 can be used for setting standards by policy makers by choosing a certain acceptable risk level, but at the same time for farmoperational purposes, on-farm monitoring and inspection too. Thus, based on epidemiological studies related to the various hazards of concern on the farm, 
we are able to identify risk conditions and to set up on-farm monitoring schemes. Risk management actions can be taken.

Some animal diseases are prevalent at the dairy farm with signs, others without signs. The same is true for zoonotic infections which may be harmful for humans but not necessarily for cattle. An example of the latter is VTEC, the verotoxigenic E.coli infection which may cause hamburger disease in humans, not causing any signs in cattle (Chapman et al., 1993). Zoonotic diseases that do cause signs in cattle can be monitored in the same way as conventional cattle diseases as pointed out above, while those that do not cause any signs in cattle have to be screened additionally according to particular protocols. These so-called carriers and shedders are a potential threat to humans by animalhuman contacts or by the animal products. Animal and zoonotic diseases should be controlled at farm level (Noordhuizen, 2003). Examples of zoonotic infections transferred to humans by e.g. milk or dairy products are listed in Table 3.

Table 3. - SOME RELEVANT MILK-BORNE ZOONOTIC DISEASES (RTVM Year Report, 2002)

\begin{tabular}{lll}
\hline Tuberculosis & milk (beef) & $* * *$ \\
Brucellosis & raw milk; cheese (fetus) & $* * *$ \\
Listeriosis & soft cheese; milk & $* * *$ \\
Campylobacteriosis & raw milk & $\left({ }^{*}\right)$ \\
Coxiellosis (Q fever) & raw milk & $\left({ }^{*}\right)$ \\
VTEC/EHEC & raw milk? cheese? & $\left({ }^{*}\right)$ \\
Salmonellosis & milk (feed stuffs) & $\left({ }^{*}\right)$ \\
Cryptosporidiosis & raw milk? & $\left({ }^{*}\right)$ \\
Leptospirosis & milk; dairy products & $\left({ }^{*}\right) / * * *$ \\
\hline
\end{tabular}

$* * *$ = also disease signs in cattle; $\left(^{*}\right)=$ rarely or not any signs in cattle, possibly carrier state; $?=$ transmission might be possible, evidence not clear

Certification procedures have been started in several countries to test herds free from certain diseases like Herpesvirus I, leptospirosis and bovine virus diarrhoea. Such an approach usually implies clinical inspection and testing of cattle and or their products (meat; milk). Testing may be performed as mass screening on cattle (blood; bulk tank milk; tissue), as individual testing (blood; milk) or as individual monitoring by cow-side tests. The first two regard laboratory testing, the third one is field practice monitoring. For both laboratory testing and clinical inspection the sensitivity and specificity should be sufficiently high in order to make justified inferences (Thrusfield, 1997). 
In addition to the hazard of diseases in cattle that may be endemic on the farm or have been introduced onto the farm by lorries, purchased cattle, humans, or from other sources, there is the hazard of contamination of the rnilk by the cow's environment. In this environment the care-takers and milkers play a paramount role, as well as the risk conditions originating from housing, climate, bedding materials, nutrition and hygiene. Contamination of the milk may occur prior to, during and after milking. High sanitation standards regarding both cows and environment in that particular time period is crucial to avoid such contamination.

Hazard identification therefore should be conducted in the broadest sense, while risk identification and risk management may assist in overcoming these hazards.

\section{Animal welfare}

Animal welfare can be considered as being based on the state of biological needs of the animal (Bracke et al., 2001). This state can be derived from scientific data, providing this definition of welfare with objectivity and transparency. The predominant questions then are, what the criteria for welfare should be, how it can be monitored and how its risk factors can be identified. Clinical inspection should address both the cows and features of the cows' environment. The epidemiological approach (see Table 2) in welfare research with risk identification has been applied on locomotor disorders (lameness), a highly welfare affecting pathological condition (Somers et al., 2003). Such an approach can also easily be applied to other welfare issues like fear in cows and abnormalities in lying behaviour. Welfare is about adaptational processes and adaptability, and not about pathophysiological zero-options.

Several reports have been published about welfare and welfare monitoring. Examples are: FAWC, 1997, Matthes et al. (1998), Ofher et al. (2000), Rousing et al. (2000), Webster, 2001. Some of these deal with index scoring, others address welfare in a qualitative sense. A well-known one regards the Tiergesundheitsindex (Animal Health Index), TGI, applied in Germany and Austria, mostly in organic farms. The TGI addresses categories like movement possibilities, opportunities for social contacts, floor design of housing facilities, climatic conditions in the barns, and intensity of care by the farmer. Disadvantage of an index is that good categories may cover up for deficient categories. The TGI has features which are comparable to those in 

animal health and welfare

good farming practice codes; hence, TGI might be called a good welfare practice code. The emphasis in welfare monitoring in general is on deviant animals as well as on risky environmental conditions on the farm.

Webster (2001) has elaborated about the "Five Freedoms" with respect to animal welfare. These "Five Freedoms" are that the animals should be free from

1. thirst, hunger and inappropriate feed

2. physical and physiological discomfort

3. pain, injury and diseases

4. fear, distress and chronic stress

5. physical limitations to express normal behaviour.

These "Five Freedoms" should then be translated into practical and clinical monitoring elements, relating to both animals and farm conditions. The FAWC report (1997) provides the qualitative basis for that purpose. Overall considered, the welfare monitoring elements are associated with the biological needs of an animal. Among the highest ranking needs are feed and water intake, resting and lying, social interactions, health and animal safety. These needs depend on internal and external conditions which are proportionally different between the different needs.

In the Annex, a prototype clinical welfare scoring list is provided (Roessel et al., 2002). This scoring list was developed on the basis of the FAWC report (1997) and subsequently tested in two veterinary practices on 91 dairy farms. The welfare could be scored at three levels: the farm overall; clusters on the farm like housing; within each cluster specific elements like slatted floor quality. Each element could be assigned a score of either 1 (poor), 3 (intermediate) or 5 (optimum). On average, $78 \%$ of the dairy farms scored the highest (best) scores, while 14\% scored lowest (poor) scores. Other results are presented in Tables 4 and 5.

Table 4. - OVERVIEW OF FARMING AREAS (ELEMENTS) WHERE HIGHEST SCORE (5) WAS ACHIEVED

\begin{tabular}{ll}
\hline Easy access to concentrate feeders & Low level of bacteria count in milk \\
Light regime during daytime & Participation in herd health programmes \\
Light regime during nighttime & Sufficient space per cow in the barn \\
Ad libitum feed available & Easy entering/leaving the feed rack \\
Absence of draught in the barn & Good quality of foot path to pasture \\
Pasturing of cows is applied & Good impression herd body condition \\
Easy rising and lying down & Good general behaviour of cows \\
\hline
\end{tabular}


Welfare disorders are like many cattle diseases, zoonotic or non-zoonotic, commonly multifactorial in nature and should be addressed following risk identification and risk analysis procedures.

As can be learned from Table 5, the most frequently found deviations are in the area of cow environment; there we can find the risk conditions possibly leading to welfare deviations in cows.

Table 5. - OVERVIEW OF FORMING AREAS + FEATURES WHERE SCORE 1 (POOR) WAS FREQUENTLY OBSERVED

\begin{tabular}{ll}
\hline Housing & $\begin{array}{l}\text { maintenance of slatted floor; cubicle design and sizes; } \\
\text { bedding material; duration of waiting in waiting area. }\end{array}$ \\
Health management & $\begin{array}{l}\text { regular claw inspection; regular condition scoring; mastitis detection and } \\
\text { prevention; herd claw trimming; claw bathing; participation in disease } \\
\text { control } \\
\text { programmes; participation in herd health programmes. } \\
\text { Pasturing }\end{array}$ \\
& quallability of pasture plots; length of pasture paths; \\
& quality of pasture paths; provision of shade and shelter.
\end{tabular}

The integrated approach: principles and rationale

Food safety, public health, animal health and animal welfare should be integrated into one HACCP-based programme because [1] disorders (the hazards) in any of the four areas are predominantly multicausal in nature, [2] hence focus must be on risk identification and risk management, [3] HACCP principles comprise such hazard and risk identification, [4] the process of production can be brought under control more efficiently and [5] therefore the product quality can be assured more effectively than by separate approaches of each aspect.

It is quite possible that HACCP-based programmes will become compulsory for dairy farmers in given EU member states or regions within a few years.

European retailers tend to strive for HACCP-based programmes on dairy farms when it comes down to assurance of health and welfare issues for animals and humans. Examples can be found at the EUREP-GAP website.

How can implementation take place?

The following steps $(\triangleright)$ are to be distinguished:

- Suppose that an initial quality assurance attitude is introduced into the dairy fanners' community. This will undoubtedly be based on good farming 
practice codes: what should be done, what should not (the do's and the don 'ts). It can be applied, for example, at the level of milking and milk storage; the use and storage of antimicrobials; nutrition and feeding management; drinking water; waste management and environmental issues; animal health and welfare issues. The farmer delivers a written statement about his milk deliveries, e.g. not marketing milk from cows under antibiotic treatment.

- Then, clinical cattle inspections may be started. The question is what should be monitored and what would be an adequate monitoring frequency? The objective of such monitoring is that one should have a justification for stating that a given herd shows adequate health and welfare, and that the milk delivered from this herd is sound.

There are several tracks along which one may achieve the objective of monitoring and for several reasons a stepwise, gradual introduction is followed:

Track 1: start slowly but steadily, with clinical inspection of cows, focusing on prevalences of disorders, and conducting that inspection a few times per year;

Track 2: as track 1, but every two years new elements are added and existing elements are extended;

Track 3: focus on incidences and more frequent visits to the dairy farm because prevalences only regard disorders of frequent occurrence or rather long (chronic) duration and in the latter situation incidences of new disorders of short duration, possibly highly severe, are often missed;

Track 4: as preceding \#3 but extended with herd testing for specific disorders like zoonones that do not lead to disease signs in cattle.

Track 5: any combinations of the preceding tracks, with variable intensity and frequency.

When implementing a certain track one should consider the sensitivity and specificity of the type of clinical inspection one applies, and the repeatability. This is particularly true in cases when the consequences of inspection are that a farm might lose its license to deliver and market milk for human consumption.

Clinical health inspection will regard issues like notifiable diseases, zoonoses, and all those disorders which have a negative impact on product safety and product quality e.g. through contamination.

For inspection of the welfare issues a monitoring list comparable to the one described above could be handled. This list is based on 12 biological needs resulting in behavioral and physiological responses. Attention cows and subsequently 'attention areas' can be listed on an inspection sheet, which serves the decision about the license to produce.

- Data inspection. Many dairy farms have different records available which are in principle suitable for monitoring and inspection, in conjunction with other named items. Examples are the milk recording forms, milk quality 
testing results, sire evaluation records, drinking water quality test results. From the milk recording forms one may for example deduce the probability of rumen acidosis or ketosis in freshly calved cows, or detect a drop in milk yield possibly due to disease. Monitoring the available farm data is, hence, a substantial part of the whole monitoring process.

Inspection of farm conditions, or the search for risk factors at the farm. Focusing the monitoring of health, welfare and food safety solely on prevailing disorders, would in general mean that if problems are present, one is often too late to react adequately, especially when prevention would have been possible. Then, failure costs already occur. Therefore, it would be better to comprise risk identification and risk analysis already within the monitoring scheme for health, welfare and food safety.

In the case of cattle health this is focused on disease risks as mentioned in textbooks, epidemiological literature, or originating from field surveys (see also Table 2 and literature reference list). For a particular farm these risk profiles must be made as specific as possible.

In the case of cattle welfare the focus should be on those areas which contribute significantly to the occurrence of welfare disorders. Examples are housing (space per cow, floor design for locomotion, cubicle design for resting and lying, maintenance standards, space for social interaction), barn climate (humidity, temperature, ventilation, draughts), feed and water availability, ration composition and quality of feedstuffs.

Therefore, any inspection focusing on welfare issues should address both the animals and the risk conditions in the cow's environment (see above).

Usually, many risk conditions from this monitoring can be placed under "General Monitoring" or good farming practice, GMP, meaning that their impact is not disorder-specific but rather related to general farming attitude and practices.

Other risk conditions are far more disorder-specific and could be ranked under critical control points (CCP) and critical management points (CMP) following a formal selection procedure (Evans \& Lindsay, 1996). The CCPs and CMPs form part of the HACCP-concept (Cullor, 1995 \& 1997; Noordhuizen \& Welpelo, 1996; Fourichon et al., 1996). Despite this formal procedure, too often CCPs are considered in the field but also in research as ordinary check points without compliance to the formal rules for CCP definition.

In a HACCP-based programme, part of this approach using critical management points and critical control points for the hazard "contamination of milk" may look as is presented in Table 6 (Lievaart et al., 2003). 
Table 6. - EXAMPLE OF A PART OF THE HACCP-BASED APPROACH FOR CONTROL OF HAZARDS OF MICROBIOLOGICAL AND CHEMICAL CONTAMINATION OF MILK DURING THE PROCESS STEPS OF MILKING AND COW TREATMENT IN THE MILK PRODUCTION PROCESS ON A DAIRY FARM

\begin{tabular}{|c|c|c|c|c|c|c|}
\hline \multirow{2}{*}{ Hazard } & \multicolumn{3}{|c|}{ Weighing risks } & \multirow{2}{*}{$\begin{array}{l}\text { Risk } \\
\text { high? }\end{array}$} & \multirow{2}{*}{$\begin{array}{l}\text { CCP } \\
\text { PoA }\end{array}$} & \multirow{2}{*}{ Preventive measures } \\
\hline & Probability & Effect & Level & & & \\
\hline Wrong drug & 2 & 2 & 4 & no & PoA & $\begin{array}{l}\text { Set right diagnosis; check label Use } \\
\text { treatment plan, worksheet }\end{array}$ \\
\hline Poor dosage & 2 & 2 & 4 & no & PoA & Check dosage; use treatment plan \\
\hline Use off-shelf & 2 & 1 & 2 & no & PoA & Check expiration date, worksheet \\
\hline $\begin{array}{l}\text { Treated cow is } \\
\text { not identified }\end{array}$ & 2 & 3 & 6 & yes & $\mathrm{CCP}$ & See worksheet \\
\hline $\begin{array}{l}\text { Antibiotic } \\
\text { residues }\end{array}$ & 2 & 3 & 6 & yes & CCP & $\begin{array}{l}\text { Identify treated cow, withdrawal period } \\
\text { respected, follow the indication, see worksheet }\end{array}$ \\
\hline Listeria milk & 2 & 4 & 8 & yes & CCP & $\begin{array}{l}\text { Milking hygiene, listeria milk not to be } \\
\text { delivered, reduce infection transfer (feed, } \\
\text { climate, bulk tank) }\end{array}$ \\
\hline
\end{tabular}

$I D=$ identification of cow; $\mathrm{PoA}=$ point of attention in farm management critical management point;

Worksheet refers to a specific worksheet e.g. on udder health management or on treatment indication and dosages

The hazards named in Table 6 may all contribute to the risk of contamination of milk. When formal risk quantification cannot be carried out, one may use experts' advice to weigh the risk probability and effect to determine the risk relevance. Preventive and corrective measures then should be developed.

\section{The Dutch way}

In order to achieve adoption among the farmers it is warranted that a gradual but steady introduction of the programme parts takes place. In the Netherlands for instance that introduction was stepwise, with steps every two years. Extending existing parts and adding new parts is the strategy of the joined efforts of the Dutch Dairy Organisation (NZO) and the Dutch Farmers' Association (LTO) since in 1998 the Dairy Chain Quality programme (KKM) was introduced (LIT).

In the KKM-programme, the first and second couple of years focus was on good farming practice issues in the 6 modules adopted: Milking and milk storage; Use and storage of medicines; Cow health and welfare; Nutrition and 
feeding management; Water, environment and waste management; Hygiene and disinfection.

In 2002 the compulsory clinical farm inspection of cows' health was added to the KKM-programme. This inspection on clinical prevalences is carried out by a trained, experienced and certified cattle veterinarian four times yearly. Inspection aims to identify those cows that comply with certain law-based disorders and from which milk is not allowed to be delivered. Additionally the farmer formally signs for not delivering milk from sick cows and or cows treated with antibiotics .

In Table 7 examples are given of the Dutch Dairy Chain Quality (KKM) clinical inspection items. Cows are being inspected for deviations resorting under one of the named categories; such cows are listed under 'attention cows'.

Table 7. - EXAMPLES OF ITEMS FOR CLINICAL INSPECTION AS IMPLEMENTED IN THE DUTCH KKM-PROGRAMME FOR THE PREVALENCE OF HEALTH DISORDERS AND CARRIED OUT FOUR TIMES PER YEAR

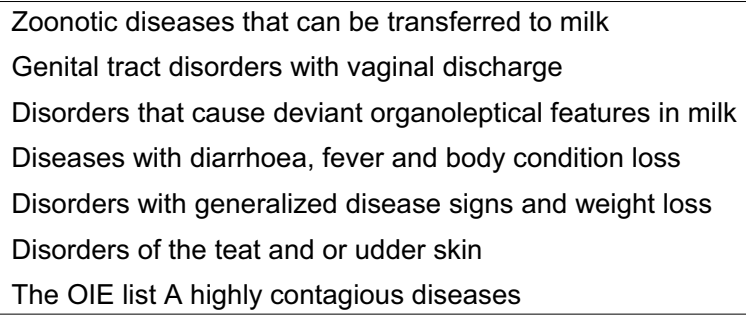

The best way for both farmer and veterinarian to execute this monitoring and inspection is on dairy farms that participate in veterinary herd health and production management programmes (Brand et al., 1996). In that case there is more knowledge of the farm and the herd in a longitudinal sense; incidences and prevalences can both be monitored. Farms in such a programme are usually visited 13 times per year; hence KKM-inspection outcome will in general become more reliable because the cow health situation is better known.

For the near future it is under consideration to include the module 'welfare inspection' in the KKM-progamme, in addition to the clinical health monitoring and based on the forenamed biological needs. Minimum requirements will be set relating to cow performance and to environmental conditions. For example, low body condition score is considered for evaluating feed intake and health but also for available space at the feed rack in case of restricted feeding. For resting one cubicle available per cow is assumed best as well as the absence of lesions and malformation of skin, joints and bones due to cubicle size and lack 
of soft bedding. Currently a pilot field test into this topic based on well observable parameters is being conducted. In that pilot study several of the items named above under welfare are taken into account. A two or four times per year inspection is foreseen. It can be envisaged that advice on housing and managing dairy cattle focusing on higher than minimum welfare standards will be developed subsequently.

It can be expected that the current Dutch KKM-programme ultimately will end up in a HACCP-based quality management programme.

\section{Concluding remarks}

In the context of the current developments at the level of both the EU and the European retailers it can be concluded that consumer protection and food safety has become the most relevant drive in relation to the production of food of animal origin.

Animal health and welfare are following as a next priority. Safeguards in these areas are required and product liability must be imposed. Dairy farmers have to show their farm status with respect to food safety \& public health as well as animal health \& welfare.

On the other hand, the citizen and the general public have their own opinion about animal products as well as production methods. This opinion is based on many aspects and is implicitly subjective. For the food chain the public image of animal products has become a major issue. A dairy farmer's license to produce and to market products is at stake.

In the dairy sector, organizations and farmers have reacted with implementing general disease monitoring systems. This monitoring, executed as clinical inspection or by blood/milk testing, is meant to obtain a general overview of the health status of the farms.

In addition, several countries have started with the stepwise implementation of, either voluntary or compulsory, quality control programmes on dairy farms. Monitoring of cows (prevalences, incidences) and farm conditions (risk factors) is part of KKM in The Netherlands. The information gathered is currently also used for on-farm consultancies by the veterinary practitioners in herd health programmes.

It can be expected that the KKM-programme will ultimately result in a HACCP-based quality management programme, where risk identification, risk management and prevention will play a paramount role. This programme will fulfill the requirements set by the EU, the Dutch government and the retailers (consumers), and at the same time will assist in adjusting the perception of the 
general public on food safety \& public health as well as on animal health \& welfare.

\section{REFERENCES}

1. Bracke, M. B. M., Metz, J. H. M., Dijkhuizen, A. A., Spruijt, B. M. 2001. Development of a decision support system for assessing farm animal welfare in relation to husbandry systems: strategy and prototype. J. Agric. And Environm. Ethics 14: 321-337.

2. Brand, A., Noordhuizen, J. P. T. M., Schukken, Y. H. 1996. Veterinary herd health and production management in dairy practice. Wageningen Pers Publ., Wageningen, The Netherlands

3. Chapman, P. A., Siddons, C. A., Wright, D. J., Norman, P., Fox, J., Crick, E. 1993. Cattle as a possible source of verocytotoxin-producing E.coli Oi57 infections in man. Epidem. Infect. 111:439-447

4. Cullor, J. S. 1995. Implementing the haccp program on your client's dairies. Food Anim. Pract./Net/Med. March 1995, 290-295.

5. Cullor, J. S. 1997. HACCP: is it coming to the dairy? J. Dairy Sci. 80: 3449-3452

6. Evans, J. R., Lindsay, W. M. 1996. The management and control of quality. 3d edition. West Publ. Company, Minneapolis/St.Paul, USA

7. FAWC, Farm Animal Welfare Council, Ministry of Agriculture, Fisheries and Food. 1997. Report on the welfare of dairy cattle. Tolworth/Surbiton, Surrey, U.K., 96 pages.

8. Fourichon, Chr., Seegers, H., Beaudeau, F., Bareille, N. 1996. Critical control points analysis for udder health management in dairy farms. Paper at the $47^{\text {th }}$ Annual Meeting of the Eur. Assoc. of Animal Production, EAAP, Lillehammer, Norway, 26-29 August 1996.

9. Knudsen, S. 1997. A quality and environmental management system developed by farmers. In: Quality management and process improvement for competitive advantage in agriculture and food. Proc. 49* seminar of the Eur. Assoc. of Agric. Econom. (Schiefer \& Helbig, eds.), Friedrich Wilhelms University, Bonn, Germany.

10. Lievaart, J. J., Noordhuizen, J. P. T. M., van Beek, E., van der Beek, C., van Risp, A., Schenkel, J., van Veersen, J. 2003. The hazard analysis critical control points concept as applied to some chemical, physical and microbiological contaminants of milk on dairy farms, a prototype, (paper submitted).

11. Matthes, H. D., Freitag, J., Goesman, M. 1998. Index of animal welfare - a criterion of subjective conditions in the keeping of cattle. Proc. $49^{\text {th }}$ Meeting of the Europ. Assoc.of Animal Production, Warsaw, Poland. Wageningen Pers Publ., Wageningen, The Netherlands.

12. Noordhuizen, J. P. T. M., Welpelo, H. J. 1996. Sustainable improvement of animal health care by systematic quality risk management according to the HACCP concept. The Vet. Quarterly 18: 121-126.

13. Noordhuizen, J. P. T. M., Frankena, K., Thrusfield, M. V., Graat, E. A. M. 2001. Application of quantitative methods in veterinary epidemiology. Wageningen Pers Publ., Wageningen, The Netherlands. 429 pages.

14. Noordhuizen, J. P. T. M. 2003. Quality management at dairy farm level: microbiological contaminants (zoonoses). EOF world dairy summit, Bruges, Belgium, September 2003.

15. Ofiier, E., Amon, B., Amon, Th., Boxberger, J. 2000. Validation of the TGI $35 \mathrm{~L}$ 1995/96 Austrian animal needs index. In: Improving health and welfare in animal production (Blokhuis, Ekkel \& Wechsler, eds.) EAAP publ. Nr. 102, Wageningen Pers Publ., Wageningen, The Netherlands, 81-87. 

animal health and welfare

16. RIVM Year Report 2002. Zoonoses and zoonotic agents in humans, food, animals and feed in The Netherlands in 2001. (van Pelt \& Valkenburgh, eds.) Inspectorate for Health Protection \& Vet. Public Health, RTVM Bilthoven, The Netherlands.

17. Roessel, S. van, Noordhuizen, J. P. T. M., Nieuwenhuijzen, D. van, Bos, $R$ van den. 2002. Clinical welfare scoring on dairy farms: prototyping (unpublished data).

18. Rousing, T., M. Bonde, J. T. Sorensen, 2000. Indicators for the assessment of animal welfare in a dairy cattle herd with a cubicle housing system. In: Improving health and welfare in animal production (Blokhuis, Ekkel \& Wechsler, eds.) EAAP publ nr 102, Wageningen Pers Publ., Wageningen, The Netherlands, 37-44.

19. Ryan, D. 1997. Three HACCP-based programs for quality management in cattle in Australia. Dairy extension NSW, Australia. Through the Dairy Discussion List Dairy-L@umdd.umd.edu

20. Schouten, J. M., Bouwknegt, M., van der Giessen, A. W., Frankena, K., Graat, E. A. M. 2001. Risk factor analysis of Oi57 on Dutch dairy farms. In: Proc. Soc. Vet. Epidem. and Prev. Med. (Menzies \& Reid, eds.) Noordwijkerhout, The Netherlands, 28th30th March 2001, 202-210

21. Somers, J. G. C. J., Frankena, K., Noordhuizen-Stassen, E. N., Metz, J. H. M. 2003. Prevalence of claw disorders in Dutch dairy cows exposed to several floor systems. J. Dairy Sci. 86: 2082-2093

22. Thrusfield, M. V. 1997. Veterinary epidemiology. Revised $2^{\text {nd }}$ edition, Blackwell Science, Oxford, U.K.

23. Von Borell, E. 2000. Assessment of pig housing based on the haccp concept-critical control points for welfare, health and manaement. In: Improving health and welfare in animal production (Blokhuis, Ekkel \& Wechsler, eds.) EAAP publ. no. 102, Wageningen Pers Publ. Wageningen, The Netherlands.

24. Webster, A. F. J. 2001. Farm animal welfare: the five freedoms and the free market. The Vet. Journal 161: 229-237

ANNEX: Clinical welfare score for dairy cattle (prototype)

\begin{tabular}{lll}
\hline General items & Veterinarian: & Farm code: \\
\hline Total number of milking cows & \\
Average milk yield/cow/year & \\
Average somatic cell count tank & \\
Average bacteria count in tank & \\
Predominant breed & \\
Type of milking parlour & \\
Degree of being closed farm & \\
Calving pattern peak or spread & \\
Yearly culling rate (\%) & No \\
Production groups present (\#) & Yes \\
\hline General husbandry
\end{tabular}

Participates in veterinary herd health

Participates in disease control programmes

Conducts condition scoring routinely

Conducts claw health score routinely

STOČARSTVO 59:2005 (1) 39-55 
J. P. T. M. Noordhuizen et al.: Quality control on dairy farms with emphasis on public health, food safety, animal health and welfare

\begin{tabular}{llll}
\hline General items & Veterinarian: & & Farm code: \\
\hline Herd claw trimming twice a year & & & \\
\hline Pasturing & score 1 & score 3 & score 5 \\
\hline Pasture is given to cows & & & \\
Quality of walking paths to pasture & & & \\
Quality of pasture management & score 1 & score 3 & score 5 \\
\hline Housing & & \\
\hline Barn climate (T; RH; draught) & & \\
Ratio cubicles - cows & & \\
Quality of bedding in cubicle & & \\
Softening elements in cubicles & & \\
Condition of slatted floor/alleys & & \\
Opportunities to fly & & \\
Available surface per cow & & \\
Ratio feeding places- cows & & \\
Ease of entering/leaving feed rack & & \\
Feeding is ad libitum & & \\
Ratio concentrate automates - cows & & \\
Quality of drinking water & & \\
Ratio water troughs- cows & & \\
Lighting regime daytime & & \\
Lighting regime nighttime & & \\
Presence of grooming brushes & & \\
Caving per/sick pen separate & & \\
\hline Milk harvesting & & \\
\hline
\end{tabular}

Duration in waiting area

Maintenance status milking machine

Cow behaviour during milking

Appropriateness of mastitis detection

Udder health action plan present

\begin{tabular}{llll}
\hline Dairy cows & score 1 & score 3 & score 5 \\
\hline
\end{tabular}

Unbalanced quarters (\%)

Arthritis cases hocks/knees (\%)

Lame cows $(\%)$

Cows on 3 legs $(\%)$

Dystocia cases (\%)

Body condition of freshly calved cows

Presence of lesions on skin, teats, udder

Presence of lesions on forehand

General behaviour of lactating cows

Score $1=$ poor/low; score $3=$ intermediate; score $5=$ goooVhigh

(van Roessel, Noordhuizen, van Nieuwenhuijzen, v.d.Bos, 2002)

KONTROLA KAKVOĆE NA MLIJEČNIM FARMAMA S NAGLSKOM NA JAVNOM ZDRAVLJU, SIGURNOSTI HRANE, ZDRAVLJU I DOBROBITI ŽIVOTINJA

Sažetak 

animal health and welfare

U kontekstu sadašnjeg razvoja na razini EU i europskih maloprodavača može se zaključiti da su zaštita potrošača i sigurnost hrane postali najvažnija akcija u vezi s proizvodnjom hrane životinjskog podrijetla. Zdravlje i dobrobit životinja slijede po prioritetu. Zaštita je potrebna na tim područjima i treba uvesti garanciju proizvoda. Proizvođači mlijeka moraju pokazati stanje svojih farma u vezi sa sigurnosti hrane i javnog zdravlja kao i zdravlja i dobrobiti životinja.

$S$ druge strane, građani i cjelokupna javnost imaju svoje vlastito mišljenje o proizvodima životinja kao i metodama proizvodnje. Njihovo se mišljenje temelji na mnogo aspekata i bezuvjetno je subjektivno. Za prehranbeni lanac predodžba javnosti o proizvodima životinja postala je glavni problem. U pitanju je dozvola proizvođača mlijeka za proizvodnju i prodaju svojih proizvoda.

U mljekarskom sektoru organizacije i farmeri reagirali su uvođenjem sustava za praćenje uobičajenih bolesti. Ovo se praćenje provodi kao klinički nadzor ili testiranje krvi mlijeka kako bi se dobila opća slika zdravstvenog stanja farma.

Osim toga, nekoliko je zemalja počelo mudro provoditi, dobrovoljno ili obvezatno, programe kontrole kakvoće na mliječnim farmama. Praćenje krava (prevladavanja, pojavljivanja) i uvjeti na farmama (faktori rizika) dio su KKM-a u Nizozemskoj. Sakupljeni podaci odmah se upotrebljavaju za konzultacije veterinara u zdravstvenim programima stada. Može se očekivati da će KKM programi konačno rezultirati programima na temelju HACCE-a za upravljanje kakvoćom pri čemu će prepoznavanje rizika, upravljanje rizikom i prevencija igrati najveću ulogu. Taj će program zadovoljiti zahtjeve koje su postavili EU, danska Vlada i maloprodavači (potrošači) a istodobno pomoći u popravljanju percepcije sveukupne javnosti o sigurnosti hrane i javnom zdravlju kao i o zdravlju i dobrobiti životinja.

Primljeno: 10. 12. 2004. 